\title{
From critique to engagement: re-evaluating the participatory model with Maasai in Northern Tanzania
}

\author{
Mara J. Goldman ${ }^{1}$ \\ Saningo Milliary \\ University of Colorado, Boulder, USA \\ Independent Consultant, Encino, CA
}

\begin{abstract}
Participatory methods for conservation and development have been critiqued on practical, political, and theoretical grounds. In this article, we address these critiques but move beyond critique to propose ways to improve participatory techniques with local communities. We discuss a customary model of communication used by Maasai communities in Tanzania and Kenya (the enkiguena, meeting) as a starting point to begin thinking about ways to improve participation on the ground with Maasai and potentially others. We discuss the value of the enkiguena ideals as a theoretical model to build dialogues across, within, and between multiple knowledge expressions and power relations.
\end{abstract}

Key words: Maasai, enkiguena, participatory techniques.

\section{Résumé}

Les méthodes participatives utilisées dans la conservation et le développement ont été critiqués pour des raisons pratiques, politiques et théoriques. Dans cet article, nous abordons ces critiques, mais aller au-delà critique de proposer des moyens pour améliorer les techniques participatives avec les communautés locales. Nous discutons un modèle habituel de communication utilisé par les communautés Massaï en Tanzanie et au Kenya (le enkiguena, réunion) comme point de départ pour commencer à réfléchir sur les moyens d'améliorer la participation sur le terrain avec Maasai, et potentiellement avec d'autres. Nous discutons de la valeur des idéaux de enkiguena comme un modèle théorique pour construire des dialogues à travers, dans, et entre les multiples expressions de la connaissance et des relations de pouvoir.

Mots clés: Massaï, enkiguena, les techniques participatives.

\section{Resumen}

Los métodos participativos para la conservación y el desarrollo han sido criticados por razones prácticas, políticas y teóricas. En este artículo, nos dirigimos a estas críticas, pero vamos más allá de la crítica para proponer formas de mejorar las técnicas participativas con las comunidades locales. Se discute un modelo tradicional de comunicación utilizado por las comunidades Masai en Tanzania y Kenia (la enkiguena, reunión) como punto de partida para empezar a pensar en formas de mejorar la participación sobre el terreno con los Masai - y potencialmente otros. Se discute el valor de los ideales enkiguena como modelo teórico para construir diálogos a través, dentro y entre las múltiples expresiones de conocimiento y relaciones de poder.

Palabras clave: Masai, enkiguena, técnicas participativas.

\footnotetext{
${ }^{1}$ Dr. Mara J. Goldman, Assistant Professor, Department of Geography, University of Colorado, Boulder, USA. Mail: mara.goldman "at" colorado.edu. Saningo Milliary, Independent education and human development consultant, Encino, CA 91436, USA and P.O. Box 14359 Arusha, Tanzania. Email: smilliary "at" hotmail.com. We would like to thank the various communities and community members we worked with in Tanzania and Kenya for their hospitality, assistance, knowledge and acceptance. In particular we appreciate the work and wisdom provided by Mungai Well, Abraham Lengine, and Alais Morindat. We are also thankful to Clive Jones and the members of the MR Steering Committee (2002-2005). Funding for this research was provided by an NSF International Research Fellowship Postdoctoral Grant. Findings also draw from research funded by a Fulbright-Hays Dissertation Research Fellowship and a NSF Dissertation Improvement Grant. We are grateful to the Tanzanian Commission for Science and Technology for supporting our research.
} 
Members of the steering committee (SC) for the new conservation area, the Manyara Ranch (MR), sat around the village school grounds, waiting patiently for the car to arrive to transport them to the ranch for their monthly planning meeting. They were only a few-five men and one woman, selected as "representatives" for this particular village to the MR. There were another seven representatives from the neighboring village and together they formed the steering committee (SC), which was mandated to represent the needs and desires of the two villages in the day-to-day management of the MR. The MR was a new multiple-use conservation area, formed out of an old and defunct state-run cattle ranch. Prior to being taken over by the state, the ranch land belonged to an expatriate rancher, who had received it from Maasai elders in the area. As the ranch came up for sale, Maasai from this area (now the two villages of Oltukai and Esilalei) asked it be returned to them, since they had never sold it, and could now use it for dry season grazing for their cattle. At the same time, conservation organizations fought for the land to be protected as an important wildlife corridor and dispersal area in between two national parks (Lake Manyara and Tarangire). In a compromise deal involving village leadership, the African Wildlife Foundation (AWF), and the local Member of Parliament, a system of "joint" management was established, with the MR to be run by a board of directors, in collaboration with the steering committee. ${ }^{2}$

The arrangement was new, and there was still a great deal of uncertainty and confusion about the role of the SC and of the MR in general. Yet (at this early stage at least) it was an uncertainty tinged with excitement about the potentials that lie ahead. For this particular small group of (mostly) men on the SC, there was the additional excitement of the possible power they had as representatives of their village, and in the running of the MR. ${ }^{3}$ Unsure when exactly the car would arrive for the meeting, they waited patiently talking amongst themselves-excitedly, nervously, about what to expect at the meeting, and about what to say. As I had my own car, I agreed to carry a couple people over to the meeting site early and in a bit more comfort then would be afforded in the overcrowded MR Land Rover. The two oldest elders and an outgoing younger one convinced the others that it was their right to ride in my car, squeezed their way in, and we were off. As we drove on the barely visible dirt road that cut across the short grass plains into the MR, the elders spoke excitedly about the meeting. They had waited a long time for this meeting and they had much to say. They explained to me in great detail why they needed to speak up and what they were planning on saying at the meeting. Their excitement was contagious. I too grew impatient for the meeting to start and was anxious to see how these Maasai elders would negotiate their speaking space with the MR manager.

As the meeting continued into the early evening and none of the elders spoke their minds as they had said they would, my enthusiasm began to wane, turning into a mixture of curiosity and concern. Why were these elders not raising any of the contentious issues they had discussed so excitedly in the car? When the manager asked for their views and opinions, he was met by silence. Moreover, not only did they not participate in the meeting in more than a very minimal way, they agreed (in their silence) to a proposal put forth by the manager that I knew they disagreed with; a plan to monitor use of MR pastures by villagers through a cattle headcount system. ${ }^{4}$ They agreed without argument, why? What prevented them from participating as they had planned? What had gone wrong? After the meeting the manager also seemed discouraged, asking me in a confused and concerned tone, "Why did they not participate? I gave them every opportunity to do so." Unable to answer him, his question further fueled my own curiosity.

Driving back from the meeting I questioned the most vocal and respected elder of the group, "Why did you not speak up at the meeting as you had planned to? Why did you not share all those thoughts you shared with me on the drive over?" His response was quick and direct, said as if I should already have known the answer, "But there was no opportunity to speak. There was no space to participate." His answer caught me by surprise. As I had observed, there was "space" to participate. The manager had asked several times for them to share their views, yet each time he was met with silence. He himself was distressed and concerned about their lack of participation, as expressed in his comments to me and in his sulking after the meeting. Now I found myself asking the very question he had asked me: Why did they not participate?

\footnotetext{
2 The history is much more complex and is covered at length in Goldman 2007 and 2011a.

${ }^{3}$ There was one woman representative from each village on the SC.

${ }^{4}$ Herders were only allowed in to graze with a certain number of cattle. See Goldman (2011a) for a more detailed discussion of this policy and the ways in which the SC members approached it.
} 


\section{Introduction}

In many ways, the lack of participation by Maasai elders explained in the above vignette should not be surprising, reflecting business as usual in "participatory" conservation or development settings. The meeting was probably called for the sake of saying that a meeting had been called, to "show" participation was attempted, even if there was no real interest by the manager or the board of directors in hearing (let alone listening to) the Maasai participants. Even if the manager was interested in promoting participation in his meeting, this does not mean he was willing to acknowledge and address the uneven power dynamics, which shaped his relationship with the other meeting participants and the larger Maasai communities (the two villages). Nor was the manager likely aware of, or even interested in, the complex power dynamics that mediated relations amongst the different steering committee members themselves. In fact, despite the manager's desire for Maasai to participate in the meeting, it was a participation he expected on his terms - in a meeting he called and chaired, along an agenda that he had set. He was not interested, in other words, in disrupting the setting: he was the professional, the expert, and the Maasai representatives were the "participants." Yet they were participants with a mixture of high expectations, trepidation and a grudge. In other words, they hoped (and expected) to jointly manage land they were still angry about losing in the first place. They wanted it back for grazing and they wanted to benefit from its success as a conservation area (e.g. through tourism). At the very least they expected to be involved in management and planning this new conservation area.

This article is about the politics of participation, with a particular focus on Monduli District in Northern Tanzania, on the two villages affiliated with the MR, which are predominately populated by Maasai pastoralists/agro-pastoralists. Findings presented here come primarily from 2.5 years of fieldwork in Tanzania (2002-2005), supplemented by additional research in three Kenyan locations and one other Tanzanian location (2006-2007). Research included observations of meetings of all types (SC, village government, clan, age-set, elders, conservation, development, and women's meetings), and long discussions afterwards with attendees, as well as over 300 interviews regarding meeting participation (2006-2007). Interviews and observations focused on communication techniques, and the ways in which individuals of different affiliations (age, gender, clan, wealth status, political power, respect) navigated the space of participation in different types of meetings. While drawing from the critical literature on participation, our goal is to move beyond critique, to combine critical theory and ethnography to effect practical outcomes for improved participation. In particular, we look at Maasai micro-politics and communication mechanisms to propose techniques to enable dialogue and encourage participation within Maasai communities and potentially elsewhere. Some modest success with our proposals are outlined. Local communication and participatory exchanges are clearly impacted by and connected to larger political economic and social dynamics. It is not our intention here to glorify the local as somehow isolated from larger power dynamics, a naïve and potentially dangerous move (McKinnon 2007; Ribot 1996; Rocheleau 2003). We are calling, rather, for a recognition of the value of certain ideals as ascribed within a particular cultural context, but of great value beyond the local, as a first step in building participatory encounters.

\section{Participation: moving beyond critique}

Academics and practitioners have rigorously critiqued participatory methods for being politically, practically, and theoretically naïve and for ignoring uneven (micro- and macro-) power relations. As such, participatory approaches to conservation and to development often reproduce the very uneven power dynamics they claim to be overturning (Ribot 1999). According to some critiques, participation merely masks domination-in the form of top-down (Western) introduced projects awaiting approval, or local elite leadership co-opting projects for their benefit (Ribot 1996). In such cases, claims of participation not only ring hollow, they can be seen as a form of "tyranny", in the sense of a misuse of power or the conscious reinforcement of unjust power differentials (Cooke and Kothari 2002). Furthermore, the "project" model of conservation and development has become entrenched in many places, including Tanzania, resulting in a local perception of development (maendeleo in Swahili) being about projects (miradi), which are brought in from the outside. Local participation in projects is often minimal, and ownership of the project difficult, since they are brought to communities from elsewhere (along with money, experts, and equipment). 
The onslaught of criticism regarding participatory methods is in many ways quite warranted. Claims about participation abound in conservation and development circles, from the World Bank to local community-based organizations (CBOs). Yet true participation of marginalized communities and individuals in conservation and development projects seems hard to find, anywhere. An alternative scenario is that participatory projects succeed at including those in power to begin with (Dill 2009). In the case of natural resource management many have argued that true participation would require a genuine ceding of power from national and international authorities to local groups and individuals over access to and management of resources (Agrawal and Gibson 1999; Nelson and Agrawal 2008; Ribot 2002; Schroeder 1999).

Participatory methods, according to Chambers (1997) were meant to turn the tables of power by asking, "Who's reality counts?" in development projects. Yet the methods proposed for such exercises are more often than not based on Western assumptions about communication and knowledge production. Attempts to get the knowledge of "others" are promoted through Western social science techniques involving structured methodologies such as Participatory Rural Appraisal (PRA). Even when such standardized methods are not employed, Western ideas of meeting facilitation, dialogue, and communication are often used to encourage participation. Just like development projects, participation is "brought" to communities. As Peters argues (1996: 22 in Schroeder 1999: 371), development workers have mistakenly tended "to assume that participation is new, that it is absent from local communities, and that it needs to be taught. . . ignor[ing] the vigor of social associations that exist in most communities" (see also Rahnema 1992).

Cooke and Kothari (2002:14-15) suggest that in order to move beyond participation as tyranny we need to "build in a more sophisticated and genuinely reflexive understanding of power and its manifestations and dynamics." The continued use and promotion of a particular model of participatory methods, even if espoused to get at other versions of reality, in fact reinforces one particular version of reality-that of development and conservation professionals. These professionals, Cooke and Kothari argue, are "engaged in the construction of a particular reality —one that at root is amenable to, and justifies, their existence and intervention within it" (p15). "Others", such as local villagers or Maasai elders, are asked to participate in a vision, a reality, which might not be one that they share. In such cases, participation can be seen as only reinforcing a particular vision, or granting permission to move ahead on already decided upon projects. In other cases, participation can fail entirely_as participants do not understand where or how they are supposed to participate-they see no space within which to do so (McCoy and Haenn 2013). The vignette with which this chapter began reflects both outcomes in one meeting:

1) Maasai elders found no space to participate, to say the many things they had every intention of sharing, and

2) all representatives agreed to an already planned project despite being vehemently opposed to the project in principle. ${ }^{5}$

Our story then, of failed participation at the MR meeting, seems to fit squarely within the standard critiques of participation. Yet, as the subtitle to this section suggests, we are interested in moving beyond critique, and beyond the standard focus within the literature on large-scale power dynamics. Rather, our focus is on a more detailed understanding of the ways in which power is negotiated at the micro-level, how communication mechanisms play a role in this process, and what a successful model for participatory encounters may look like. We suggest that the best way to do this, echoing the insights of Peters, is to pay close attention to the social processes that already exist in the places we work to promote dialogue and decision-making. So while we see the value and need for Cook and Kothari's focus on power dynamics, we are drawn to their particular insistence that we open and deepen our reflections of participation-to different ways of seeing and knowing, and we suggest, communicating. The words of a Maasai development worker nicely reflect the need for this sort of move:

\footnotetext{
${ }^{5}$ Their agreement could also be seen as a maneuver by the SC to do what was expected of them, but with little intent on following through. They agreed to restrictions on grazing and then systematically broke the rules. To the manager this was an abuse of power. What he did not see was a way for the SC members to assert power, in an otherwise powerless relationship. They did not have the power to disagree, but they did have the power to break the rules as they saw fit (Goldman 2011a; see also Scott 1987).
} 
We need to interrogate methods of communicating about development. Many development projects fail not because of bad intentions or motives, but because of failure to hear and get views from those for whom the project is designed. Even when you use existing participatory methods, they are limited and alien. So you fail to capture what people know because it is not the way the people normally share their views. So if you use a method that people are not used to, you get the wrong views, half the views, or none! ${ }^{6}$

In Maasai communities of Tanzania and Kenya, all formal decision-making occurs in meetings, referred to by Tanzanian Maasai as enkiguena. ${ }^{7}$ We suggest that the enkiguena, as a formal Maasai institution for communication and decision-making, reflects many of the tenets of participation, even if it does not fit a Western model of democratic voting, representation, and order. We also suggest that when the communication structure shifts from this norm, as it did in the SC meetings in the MR, Maasai find that there is no space to participate-the structure does not allow for it. We suggest that the process of creating this participatory space, at least with Maasai communities, does not lie only with recognition of power dynamics. Power is of course always present and affecting outcomes. Yet power is not all determining-it is acquiesced to, resisted, and manipulated in different ways by different individuals, in different contexts. When it comes to official decision-making contexts, the very structure of the meeting enables different types of articulations and manipulations of power and thus, different kinds of participation. ${ }^{8}$

We propose the enkiguena-a customary (yet changing) model of communication used by Maasai communities themselves - as a participatory tool to engage with Maasai communities, in recognition of multiple, complex, and overlapping power dynamics. For theoretical as well as practical reasons, the enkiguena structure allows an engagement with multiplicity without giving into politics as usual. In a sense, we are formalizing sentiments made by others regarding Maasai decision-making. A study on participatory politics in the Ngorongoro Conservation Area (NCA) ${ }^{9}$ concluded that, "[t]he way the Maasai solve conflicts by open discussions and with the elders as conflict negotiators can possibly provide a model for more openness and conflict resolution in NCA" (Rugumayo 1997: 297; see also Western 1997). After a brief introduction to Maasai social relations, we explain what such a model looks like in its ideal form.

\section{The Maasai case study}

\section{Metumo ildoinye, kakai tumo iltunganak \\ (Maasai proverb, "Mountains do not meet but people do")}

Maasai are a predominately pastoral people, although today most also cultivate crops (usually maize and beans) for subsistence and profit, and many men and women participate in alternative income-earning activities such as wage-labor (McCabe 2003), gemstone trading, cattle trading, and "petty-trade" in beadwork and small commodities. Occupying an area that stretches approximately 100,000 $\mathrm{km}^{2}$ across the TanzanianKenyan border (Talle 1988), Maasai combine contemporary government territorial distinctions (villages in Tanzania, group ranches or divisions in Kenya) with complex customary social and spatial distinctions. Customary institutions segregate and unite Maasai society across space, kinship, age, and gender. "Maasailand" is divided into different territorial sections, iloshon (pl; olosho sg.) that are further divided into

\footnotetext{
${ }^{6}$ Interview with a Maasai man from Ngorongoro District, Tanzania who worked for the international organization OXFAM, June 2006.

${ }^{7}$ Other words are also used such as entumo (to meet), popular in Kenya. Enkiguena is a more complex term encompassing the very ideals of communication and participation central to Maasai society.

${ }^{8}$ The meeting described above, for instance, likely had inner workings and power dynamics that impacted why certain elders did not speak and why they all agreed in the end. It is also possible that an influential elder partnered with the manager to "make a deal." However, had the meeting been conducted in enkiguena style, such "deal making" would have been visible to the others- it would have been exposed in the dialogue, and could have been challenged in small ways by different speakers.

${ }^{9}$ NCA is a multiple use conservation area in northern Tanzania managed for wildlife and forest conservation, tourism, and Maasai (see McCabe, Perkin and Schofield 1992).
} 
sub-sections, inkutot (sg. enkutoto). The main focus in this article is on the Emanyara Enkutoto within the Ilkisongo section, the largest section in Tanzania stretching into Kenya.

The different inkutot and iloshon remain linked horizontally through seven major clans (ilgilat) and numerous sub-clans (enkishomi), and vertically through a shared age-set system. Men from different sections and clans are thus connected under one named age-set. At circumcision, young boys become ilmurran (olmurrani, sg. often translated as 'warriors') and enter a new named age-set to which they will be connected for the remainder of their lives. ${ }^{10}$ Men then progress together with their age-mates through a series of ceremonies where they become (as a group) senior ilmurran, elders, and finally retired elders. The age-set system creates strong life-long bonds among age-mates, but it also separates men from different age-sets, effectively mediating interactions among men and between different age-sets of men and women of different age-grade classifications. Women do not belong to organized age-sets, though in many areas they organize themselves into named "groups", based on the timing of their initiation into womanhood. ${ }^{11}$ Generally, women progress from being young girls (endito sg., intoiye, pl.), to young wives (sangiki sg., insangikin pl.), to mothers (yeiyo), to grandmothers (koko), and are recognized as being affiliated with the age-set of their husband. Men and women are also separated and connected through clan categories. Women are recognized as belonging to the clan of their husband, but with remaining loyalty to their father's clan. These overlapping categories of belonging and division are important for understanding power dynamics, social relations, leadership, and communication structures. Age-set and clan relations mediate interactions among men and women (i.e. sexual relations, eating, social exchanges, communication). They also demand overlapping leadership structures and diffuse and shifting power relations.

\section{The enkiguena in practice: mediating power and participation}

The enkiguena is central to Maasai governing organization and leadership structures. It is the tool of arbitration used to settle conflicts, make decisions, and organize events-particularly for elders and for ageset and clan leaders, ilaigwenak. However, while in practice an enkiguena is often dominated by the elders, as a theoretical ideal it is a model structure utilized by men, women, youth, elected and traditional leaders, neighborhood elders, a family, or a boma (Maasai homestead). ${ }^{12}$ The literal translation of enkiguena is discussion, meeting, consultation, debate, or counsel (as in legal dispute) (Mol 1996: 181). ${ }^{13}$ The word for leader, Olaigwenani (pl. ilaigwenak) shares the same root as the word for enkiguena. The literal translation of Olaigwenani is 'spokesman', and such men are chosen for their abilities at an enkiguena, which includes speaking, listening, delegating, and providing others the opportunity to speak. ${ }^{14}$ Ilaigwenak exist for age-sets and clans, reflecting overlapping power dynamics and obligations. The subjects dealt with at an enkiguena can range from day-to-day problems, such as the theft of a goat, age-set transgressions, and clan assistance needs, to more complex issues, such as questions of inheritance, warfare, and cases of murder (see Saitoti 1980: 187). They can also cover government issues, such as grazing plans, land use, contributions (taxes), legal matters and development and conservation issues. Decisions made at any enkiguena are determined by consensus, discussed more below.

At the general level, it is possible to group the various kinds of enkiguena into two types. There is on the one hand, the enkiguena that calls together people to make a joint decision on a matter, which concerns them all equally, such as a village development project or an age-set celebration. On the other hand, there are

\footnotetext{
${ }^{10}$ The importance of age-sets, and of the time period of being ilmurran is reflected by the fact that historical events are recalled by Maasai in relation to what age-set was ilmurran at that time.

${ }^{11}$ This has not been discussed in any of literature, but I have found named groups to be consistent across Maasai communities in Tanzania, with the exception of Simanjiro District. These names provide a finer separation of large groups of women married to the same age-set of men.

${ }^{12}$ Boma is Swahili for the typical Maasai residential unit, a grouping of houses of different polygamous families around a single cattle kraal, encircled with a thorn fence. Boma is the commonly used Swahili term, which is most dominant in the literature. The Maasai word is enkang (inkangitie, pl). Homestead is an English equivalent, and older references include "villages" or "kraals."

${ }^{13}$ Maasai continue to use their own mediation techniques such as enkiguena to resolve legal disputes such as theft, marital issues, custody, and inheritance rights.

${ }^{14}$ Ilaikwenak have traditionally been men. A new project introduced by two local NGOs (Ujamaa Community Resource Trust and The Tanzanian Natural Resource Forum), is formalizing new groups of women leaders, engaiguenak, to work on their own as well as together with the men in a "customary leadership forum" (Goldman 2011b).
} 
meetings called primarily to arbitrate between two disputing individuals or parties. In the latter situations, the individuals involved rely on their ilaigwenak to speak/arbitrate their case for them, and will often travel a good distance to locate one and request his presence at the enkiguena. In such cases the Olaigwenani will act as a lawyer of sorts for his concerned party, he will be his official representative. The principles governing each type of enkiguena are the same, albeit with differences in the type of consensus to be reached. That is, while the first type of enkiguena will strive for a true consensus as a sign of unity within a defined "community" (age-set, village), the second type will be more an arbitration between disagreeing parties (or the representatives/spokesmen for the parties). Both types of consensus, however, are respected as the final word by all involved, because they are created through the very process of debate, which is the foundation of the enkiguena.

Our interest in the remainder of this section is to outline the principles underlying the enkiguena and the ideals, which it upholds. We do not intend to suggest that such ideals are always carried through, but rather that they provide a valuable template to begin building participatory dialogues.

\section{The enkiguena ideal: context, format, and principles}

There are three primary principles underlying the enkiguena structure that make it an ideal setting/context for participatory dialogue. First, debate is opened by naming only the problem at hand (e.g. the issue "concerning" the dam, the issue "concerning" the school, a theft). ${ }^{15}$ There is no mention of possible solutions within the problem statement itself or by the person who opens the meeting (i.e. to vote if we should place the dam at location $\mathrm{X}$, to decide if $\mathrm{Y}$ should be fined $\mathrm{X}$ number of cattle for the theft). Second, everyone at an enkiguena has the freedom (theoretically) to speak and to be listened to; there are no rules constraining his/her contribution. And lastly, a meeting is finished when, and only when, a consensus has been reached. In other words, a meeting is finished when everyone agrees to an ending, which is "sufficient to stifle further protest" (Spencer, 2003: 25). This final principle is difficult to understand, and is not appropriately described with the English word "consensus" and is discussed in more detail below. Here, we would like to explain the general setting of an enkiguena, and discuss how the first two principles play out.

An enkiguena is often held under the shade of a large tree, or inside an empty classroom or village office. Regardless of the setting, there is usually an attempt to make a circle, where the speaker can stand in the middle addressing all, rather than standing in front as if on stage. Women will often sit together slightly separated out from the men, though this is changing in many Maasai communities with women taking a central role in meetings and mixing in with the men. All meetings are opened with a blessing by one of the senior elders present. Then, the one who called the meeting (or the Olaigwenani or village chairman) will explain the nature of the problem. If the case involves a feud between two people they will both have their chance to present their views (see also Saitoti 1980), or this will be done by the Olaigwenani of each side, playing the role of representative. If it is a government meeting, the issue at hand will be described as an agenda item. Regardless of the type of meeting, it begins by stating the issue to be discussed, and the floor is then opened up for dialogue.

Everyone present at the meeting (including visitors not from the area) has the chance to speak, if they have something to say and the courage to speak to the crowd. When someone wishes to speak they stand up in the center of the circle so they can address the entire crowd, often turning to look in different directions as they talk. Important elders and ilaigwenak will hold a specially carved stick, called an olkuma when speaking, as a sign of their respected status. Other men will hold onto their walking stick, leaning on it authoritatively, or confidently holding it against their back, as they turn to speak to the crowd. ${ }^{16}$ Historically, women often did not attend meetings with men, and when they did they spoke while sitting and without a stick/prop of any kind. If a woman did stand, a man would need to stand up at the same time. While today Maasai women have become actively involved in village meetings and in some communities (in Simanjiro, Loliondo, and Longido in Tanzania, Kaputei and Purko in Kenya) women stand and speak freely, among

\footnotetext{
${ }^{15}$ Even when speaking in Maasai, literate Maasai often use the Swahili word kuhusu, when presenting an agenda item. Kuhusu means 'concerning', 'in regards to' and is thus a completely neutral way of addressing a topic.

${ }^{16}$ Holding onto a stick of some sort is essential for men that stand to speak at an enkiguena. If someone does not have a stick they will be lent one to hold while they stand and speak. For some the stick enables a more authoritative tone, a tool to diagram and point with. For others it is a crutch, to lean on and hide behind.
} 
many of the Kisongo Maasai women still speak while sitting. ${ }^{17}$ At government and NGO meetings, women will often be called on to speak if they fail to speak up themselves. All others must request to speak. There is no rule over who can and cannot speak; the "chairman" for the meeting just makes sure that everyone who wants to speak has his/her chance. Relations of respect and power as associated with wealth and age are of course, ever present, even at an enkiguena, but individual personalities determine who dominates the discussion at an enkiguena. The most influential speakers are those "who can grasp the opportunity persuasively," and weave the various strands of dialogue "into an imaginative synthesis" (Spencer 2000: 249). Structural power dynamics, while always present, do not necessarily constrain a person's ability to speak at an enkiguena, they do not dominate the flow of the meeting. ${ }^{18}$

At an enkiguena each speaker speaks until s/he is finished, regardless of how long this might take; then and only then does another stand to speak. When speaking, there is no constraining etiquette speakers must follow, they are free to speak their concerns, voice their anger, show their lack of interest in the topic being discussed, and even insult a prior speaker; as long as it is done during their turn to speak. Negative words or interactions exchanged at an enkiguena are left at the enkiguena, with differing parties and individuals holding no grudges afterwards, at least in theory. For the most part, everyone's experience or knowledge is respected and considered relevant, and in some ways contributes to the final decision that is made. Speaking at a meeting, as such, indicates some degree of ownership over the final decision, the consensus. Not speaking (silence) indicates agreement with the consensus, but not ownership of it. A meeting can take all day, much gets repeated, and the conversation may go in unexpected directions. ${ }^{19}$ This process was explained by a Maasai junior elder to his mzungu (Euro-American, sg. wazungu pl.) guest who was clearly confused trying to follow a meeting that was being conducted in Maasai style (ya Kimaasai):

We do things the Maasai way; we do not know how to shorten things [kufupisha], like you wazungu. We can take a very long time, but it is like this: one person goes into detail [anachuja], another makes an error [anakosea], another goes far off the topic [anaenda mbali], and then we return right there [pale pale]. If you try to have ten agenda items in one meeting, you can't. It is not like those [meetings] of wazungu, or even ... those other people who have developed [watu walioendelea]. You can have only two agenda items and still it will take a very long time. Until most of the people present have stood and spoke.

An individual can stand to speak multiple times, with something new to say each time, as the dialogue progresses, twists and turns and a consensus is constructed. It is only when nothing new is being said that the chairman of the meeting may try to prevent someone from speaking again, or may cut short the long-winded words of a speaker. At this point the chairperson of the meeting will try to see if there is agreement on a consensus by asking something like, kirukote [we have agreed], Kituningote [we have embraced each other's ideas/heard/listened to each other] or simply, Kindipa [we have finished]?

So how is a consensus reached? There are no choices put forth and there is no voting. Voting, according to some Maasai "corrupts", for it hides the processes of negotiation. As a group of ilaigwenak explained, "Voting corrupts. It is better to discuss and if we fail to agree we will postpone [the decision]. Voting has no truth." Voting is seen as directly linked to politics, which is associated with lies and deception. The dialogue at an enkiguena rarely follows a linear path. It circles around and meanders off in different directions as different speakers contribute new ideas, knowledge and opinions to the topic at hand. People will often draw on memory to discuss how a similar problem was tackled in the past, what they decided then and if it is relevant to the current discussion. The different words presented by different speakers slowly piece together a collage, or as Spencer suggests "an imaginative synthesis" (2000: 249). The "synthesis" is

\footnotetext{
${ }^{17}$ The reasons for these differences could be related to different levels of church involvement, and women's involvement in politics in the different areas.

18 There was one individual whom I always saw actively involved at enkiguena, usually speaking with confidence and listened to intently. I was confused because he was young, poor, uneducated, and not a leader of any kind. It was explained to me that he was a good speaker and thus commanded the attention of an elder.

${ }^{19}$ For instance, if the discussion is in regards plans for the school and an elder stands and begins talking about his cattle, there is no reason to stop him or to believe that his story will not in some way, at some point, reflect on the topic at hand.
} 
imaginative in that there is no formal construction of a compromise. Imagine for instance a meeting regarding an age-set transgression (i.e. senior ilmurran behaving towards the junior ilmurran in a way that violates expected norms, such as use of excessive violence). At the enkiguena, one speaker suggests the entire age-set be fined ten bulls and five calves. Another speaker argues against livestock contributions altogether demanding a fine of cash and alcohol. Others scoff at this and recall the time when cattle only were used for fines and the ilmurran knew how to behave. Several speakers argue against a fine at all, and push for forgiveness. No one suggests that a compromise be met between the different extremes that will make everyone happy. Yet as more people speak, it becomes clear that a fine is necessary (they have always done so in the past), and what an appropriate fine should be (today things are different, money is easier than cattle). Most people believe the fine should be some combination of cattle and cash, and of course alcohol. Various possibilities are suggested; different cohorts push for particular conclusions until a statement is made which encapsulates enough of the variability expressed and provides a solution agreeable to all. All are satisfied with the consensus because their voice was heard and no one voice dominated the debate or predicted the outcome. The final agreement may not reflect the wishes of all (such as those being fined!), but it is acceptable to all. It will be final. ${ }^{20}$

It is, of course, not always the case that all present at an enkiguena agree completely and are happy with the final consensus. Sometimes, one voice or a group of voices dominates the meeting, pushing through a particular agenda item. Other times a minority opposing view may have trouble getting their voice heard or taken seriously. And other times, intimidation and fear associated with social relations may keep particular voices from being heard (such as those of women and the youth, discussed below). The value of the enkiguena format is that the dialogue is open and the power dynamics exposed through the debate. The consensus is thus often discussed in this manner afterwards, in terms of how it was reached and why.

Maasai can deliberate all day long until a consensus is reached. As David Western observed, "...time is not a limiting commodity among the Maasai. Discussion, trust, and consensus are everything. Every view is voiced, carefully weighed, and finally arbitrated" (1997: 93). An important point here is that a consensus is built through dialogue, not voted on. It is final when no one has anything left to say. It does not reflect agreement of all on a particular idea, but rather an agreement to respect a particular outcome. In other words, while not a "majority" rule, a consensus is an agreement to agree with the most compelling decision-the one most spoken about at the meeting, the decision that most agree with. The chairperson of the meeting will often summarize the conclusion of the discussion and (if relevant) set the schedule of events (or payments) discussed or otherwise plan for a follow up meeting. The consensus will then be blessed by one of the oldest elders at the meeting. Sometimes, an entire day is not enough time to reach a consensus and a meeting will reconvene until one is reached.

In certain circumstances a consensus will not be final, and can be revisited. In other words, if some were not satisfied with the meeting outcome, felt that they were not well represented, or that the meeting was not conducted properly, there is recourse. For instance, if the meeting discussed above was lead by the ageset in direct conflict with the one being fined, or if a meeting is dominated by the ilaigwenak from one particular clan (or moiety), complaints are often put forth and a new meeting held. What remains important to the success of an enkiguena and overall acceptance of the consensus is representation of all the variety of possible opinions. This does not mean there needs to be equal numbers of people present representing different social groups, but rather that the dialogue should encompass and reflect the differences that exist within the community. Women, for instance, can refuse to take seriously a decision made at a meeting for which they were not present, and demand a new meeting be held. The consensus, of course, also needs to be applicable. A man cannot be fined five cattle if he has none, but will instead be fined one goat. However, as the consensus is built, the desire to fine him five cattle (because of the weight of the crime) will become known to all.

\footnotetext{
${ }^{20}$ This draws roughly from a series of meetings the lead author observed regarding a fine against the Landis age-set for using excessive violence against the younger age-set.
} 


\section{Participatory politics: knowledge, respect, and unity}

Multiplicity (difference in knowledge, expertise, and opinion), respect, and unity (consensus) are interwoven in the dialogues enacted at an enkiguena. Respect for all participants to speak until finished encourages multiple perspectives on an issue, while a shared vision of unity encourages the enactment (through dialogue) of a consensus. In practice, however, unity (a consensus) can seem like a lofty and difficult ideal to maintain (even to Maasai). Respect is not always universal and can restrain as well as facilitate dialogue, even in an enkiguena. In this section we briefly touch on how Maasai define unity and respect and how these notions are linked to participation and the politics of knowledge. This is important for understanding how knowledge is exchanged among Maasai and between Maasai and outside groups and for building participatory settings.

In her work on participatory politics in Ngorongoro Conservation Area, Rugumayo (1997) found that Maasai saw respect and unity as the foundation of any participatory process. According to one Olaigwenani who took part in negotiations with the management authority, the Ngorongoro Conservation Area Authority (NCAA), "participation is a question of respect, that you should not feel embarrassed because you cannot read [i.e. the new management plan proposed by NCAA]. You should be respected. Participation is about truth by whomever" (Rugumayo 1997: 286). This statement reflects the need for someone to feel comfortable to be able to participate on their own terms. A womens' group similarly argued that, "participation should be based on firsthand information; we should be able to look into each others' eyes, be self-critical and honest. Since it restores dignity and access to latent treasured wisdom, even if by a woman" (Rugumayo 1997: 284). Without respect for Maasai knowledge, they argued, there could be no unity between Maasai and NCAA, which, in Maasai eyes, meant there could be no real participation (ibid.). One elder Rugumayo spoke with argued that "participation means a relationship with people ... without tricks to each other, people who share information openly, people who join their physical and intellectual efforts into achieving the agreed objectives, without ever caring what is the status of the partner."

The case that Rugamayo was looking at was particularly contentious and controversial. The NCA had put together a new management plan for the area that would impact the lives of the several thousand Maasai residents. They claimed to have used a participatory method, because Maasai received the plan to review and comment on prior to acceptance. As the above statements suggest, for the Maasai of NCA, this was not participation. In order for their voices to be heard resident Maasai participated in a video project where they were able to speak their concerns (rather than have them written, as many Maasai are illiterate), and presented this to the NCAA and donor agencies involved in the management planning process. The process was participatory, but was rejected as "political" by the governing and funding agencies (Taylor and Johansson 1996). Yet for Maasai, "politics" is the very deception involved in keeping particular views hidden from sight.

The above statements made by Maasai of NCA, attest to the importance of "equality" among Maasai, something that has been the focus of much anthropological intrigue (Ndagala 1992; Rigby 1985, 1992). The focus in the literature has been on material equality and the tension between the ideal of equality and the reality of the unequal distribution of wealth within Maasai communities and households (Ndagala 1992; Talle 1988; Thompson and Homewood 2002; Waller 1999). Some have argued that it is the ability for any Maasai-in theory and practice - to 'become rich' through the combination of luck, hard work, and skill (as well as inheritance), that maintains the validity of the equality ideal. Similarly, in public and private debate, in the context of an enkiguena, all have equal opportunities to speak, to be listened to, and to be respected. A wealthy man may be particularly influential in decision making, but prestige, respect, and admiration is enhanced from the personality of the individual and their ability to communicate (cf. Saitoti, 1980: 186). For instance, in Emanyara there was a case of a young man not commanding respect at meetings, and not having his words taken seriously, despite his extreme wealth and power in the area, because he could not speak well and was not considered very "wise." He may be wealthy, people said, but he is not yet a man, he does not even know how to talk at meetings! On the other hand, someone who is poor with no direct connection to power may dominate a meeting because he possesses good oration skills, or is skilled in seeing the bigger picture and tying it all together. 
As stated above, ilaigwenak (customary leaders) are respected because of their integrity, communication skills and leadership qualities, which includes generosity and an easygoing temperament, and especially their ability to speak at meetings, but has nothing to do with wealth. The topic of discussion at an enkiguena can clearly impact who speaks and whose words are respected more. Topics concerning money, development and other "'modern" issues draw heavily from the knowledge of the younger generation, while topics that can draw on memory (i.e. how a problem was dealt with in the past), rely heavily on the elders. However, who speaks, what gets said (and not said), and who is listened to more at an enkiguena is also tied to relations of trust and friendship, as well as fear and respect of power and authority. Respect, as such, plays out in different ways at an enkiguena. There is respect for the contributions of all, but feelings of fear associated with respect can keep certain people from speaking after others. In such cases, "participation by proxy", is often used, where someone (or a some group) can have someone else speak on their behalf.

The Maasai notion of respect (enkanyit) can inhibit some from speaking in front of others because of "fear" associated with respect and social norms governing behavior (Hodgson 2001). Enkanyit can, for instance, inhibit open discussion by young men in front of elders, and women in front of large groups of older men, or in front of individual men with a particular clan affiliation (endalepo). Certain categories of women, such as widows, the wives of very old (retired) elders, the mothers of respected leaders, and female political leaders, are usually free from the constraints of enkanyit at meetings. Similarly, young men of respected status (because of money, education, or affiliation) may also speak freely and without fear. These are, however, only generalizations, as discussed above, personality and communication skills play a large role in who speaks when and how.

In recent years, women and youth have been encouraged to participate more fully in meetings held by village governments and NGOs (local, national and international) regarding village governance, development or conservation matters. However, such participation is often encouraged only by inviting women to attend a meeting and then asking them to speak. Without recognizing the barriers that may exist, inhibiting particular individuals from speaking in front of others, such attempts often fail. Meetings held separately with women or youth, in such cases, can be much more effective for enabling their participation, as can providing women with an agenda ahead of time so they are prepared for the meeting and can plan for certain people to speak for them (other women, or men). Yet at the same time, more women have begun attending the "meetings of men" regularly, when the issue is pertinent to their lives and they do not trust the men to work it out fairly. They are learning that if government related decisions are made without them, it is against Tanzanian law. They thus have a right to refuse a decision's legitimacy if they were not included in the decision making process. A recent dispute in one of the study villages for example was contested by women who refused to acquiesce, even as the men finally did. Men, they argue, will give in to a decision they disagree with because of their fear of losing popularity, of angering an age-mate or an elder they respect, and of decreasing their opportunities for "good" reciprocal relations down the line. They themselves, the women argued, do not have such fears and are more likely to stick to their argument once they have the courage to speak it. Older women can often say almost anything at a meeting and when they do so, they are usually listened to by all with a great deal of respect. In fact, many men acknowledge that when women in general speak, their words are often respected, expected to reflect the "truth' rather than politicking. The space of an enkiguena is open and the words spoken there hold power.

The notion of respect also plays a major role in interactions between Maasai and outsiders. This is true with the positive/engaging aspects of enkanyit associated with listening to and respecting different opinions, as well as the negative/constraining aspects associated with fear and deference for authority. The relationship is complex: respect is both vital to and inhibiting of participation. As discussed above for Maasai in Ngorongoro, the notion of joint respect and unity is seen as essential to Maasai for participation to occur. However, when a meeting is held in a manner which they are unfamiliar (i.e. Western format), and the organizer(s)/leader of the meeting is someone whom they respect or see as being in a position of authority, their participation will likely be constrained.

This can explain in part why the SC meetings in the MR failed to elicit participation by the Maasai village representatives as described in the opening vignette. Meetings were conducted by the ranch manager 
in a Western-style. ${ }^{21}$ He always had an agenda with multiple items to be discussed, all which would be read at the beginning of the meeting. This reading would usually involve his opinion of the best solution or course of action regarding a particular agenda item to which he would then solicit comments from the committee. After talking at length, he would inevitably say something like, "I have much more to say but I would like to give you all a chance to speak. I want to hear what you think," which was nearly always met with silence. After the above discussion of the structure of a Maasai enkiguena, the reason for the silence should be clear. First, the manager leading the meeting openly said he was not done speaking, it would be disrespectful, unthinkable, for a Maasai to begin speaking until the manager (who was an elder) was done. Second, the manager was someone whom they respected and saw as an authority. This was confounded by his placement at the front of the meeting space (with all others facing him). Since he had proposed a possible conclusion along with the presentation of the agenda, he had foreclosed further discussion. The agenda item, for many Maasai, had already been decided. The meeting, as such, was closed; there was no further space for participation. This is not a situation unique to the Manager of the MR, but a common feature of nearly all meetings led by members external to the community. It even occurs regularly with Maasai NGOs working in the area. After one such meeting observed by one of the authors, held by a Maasai NGO in one of the study villages, the man who had led the meeting asked why people did not participate. He was told that he should know, he was Maasai and the way he structured the meeting left little room for participation. He had presented a problem together with a solution as the agenda item, asking for feedback. For Maasai at the meeting, it would have been disrespectful for them to disapprove and suggest another possibility. The man agreed, seemingly surprised at not recognizing this himself. Many Maasai NGO leaders are Westerneducated and feel pressured to use a Western-style meeting when they visit villages to share information and to receive ideas from community members. The quote above from one Maasai development worker suggests they are well aware of the limits of this system, yet seem to be caught in it. "Development" is recognized as being an outside intervention, one that comes with its own processes of promotion, meetings, evaluations, and communication. NGO workers, even Maasai ones, do not think about using a Maasai communication structure such as the enkiguena, in such contexts. This is being challenged today by one local Community Based Organization (CBO), Ujamaa Community Resource Trust, as discussed below.

\section{Learning from the enkiguena: exposing power dynamics}

We suggest that the enkiguena structure meeting-with its circular shape, its open agenda, and freedom for all to speak-makes it difficult for power dynamics to dominate the terms of engagement. All views are made visible; the physical space of every individual is clearly affirmed but individuals are not distinguished, they sit together and look at each other. If a wealthy person abuses his power, it is noted and not accepted. Power is at play always, but it is open, understood, and worked around. In 2004, we proposed to members of the SC of the MR, that they run their meetings in the structure of a "Maasai-style" enkiguena, to encourage more participation. They were open to the suggestion, but were skeptical that it would change much. What did it matter how the meeting went, they asked, if in the end they had no power? "They were only puppets", one man insisted, being pulled by powers higher up. They argued for the need to have more control and to see benefits from the MR. That, they argued, was more important then a transformation of the meeting style, though they were excited about trying to switch the meeting structure and recognized it as a good start. Other Maasai, involved as liaisons between the MR or other conservation related entities and Maasai communities, saw the inherent value of the meeting shift. Yes, it was just a start, but it was a big gesture. It would enable participation. It would enable power shifts. It would be a beginning and a necessary component of any future democratic management of the area. It was a sign of good faith. The "test" meeting of the SC did create the space needed for Maasai to participate. In fact they took over the meeting.

If the shift of meeting style to an enkiguena in the MR was just a sign of good faith, and did not change much on the ground in terms of power and control within MR management, is that really enough? We suggest that it is an important and necessary first step that may have just come too late for the MR and that it

\footnotetext{
${ }^{21}$ In bringing this up at a meeting, the manager suggested the style was dictated by Tanzanian culture rather than "Western" culture. He was not comfortable with it either, but as the "manager" it was expected he would run a meeting in such a way. It can be seen as a colonial structure, further enforced and formalized through Tanzanian governance culture.
} 
is an important step for other organizations to take. For the MR, by the time the suggestion had been made to the SC, much time had passed and many meetings had been held, where Maasai SC members had struggled to find a way to participate. Failing in many ways to do so, there were ripple effects back in the villages. These SC members were representatives_charged with bringing information back to the villagers, and bringing village needs and concerns to the ranch. But how were they to do so if they did not feel comfortable speaking at meetings that were directed by the manager in a way that foreclosed discussion? Several SC members expressed their frustration with this and with having little control over decisions made in MR in ways that they were embarrassed to express to their constituencies. Giving them some control over the meeting structure could have offered some space for new kinds of negotiations; although it is possible it was offered too late in the process.

Beyond the MR, there were several other instances in which conducting a meeting as an enkiguena might contribute to more than just a "sign of good faith." First, it reflects a particular respect for Maasai knowledge and way of doing things, a respect not often afforded by visiting conservation or development "experts," even when these experts are Maasai themselves. Steeped in Western education and training, Maasai NGO leaders often make many of the same communication mistakes with Maasai as explained for the manager of the MR above. Proposing the enkiguena structure (and in some cases all day meetings), is an attempt to turn the tables in the way that Robert Chambers (1997) suggests is necessary, when he asked, "who's knowledge counts?" While Chambers provided Western techniques of inquiry to address this question, we suggest using a local technique. Secondly, we suggest that the ideal principles associated with the enkiguena provide an appropriate framework for building dialogues within and across diverse knowledge claims. Again, these principles include:

1) open ended agendas (e.g. the problem statement only),

2) freedom (without constraint for order) for all to speak and to be listened to, and

3) dedication to reaching a consensus that is acceptable to all.

Can such changes in communication structure actually address the uneven power dynamics that frame conservation and development processes? We suggest it is at least a start. Clearly not all organizations are interested or willing in what local communities have to say, or what local needs are regarding conservation or development. However, as stated above, there are some organizations that are working with good intentions, yet using the wrong methods. Perhaps more important still, if local communities can demand local communication structures be used for negotiations with outside agencies, the power begins to be slightly destabilized. Drawing on a Foucauldian notion of power is useful here to understand how this may happen. Timothy Mitchell (1990: 558) discusses this notion of power as "a disciplinary mechanism so persuasive and yet largely so unseen that the ordinary individual is persuaded to become involved in the continuous monitoring of his own actions." As Foucault (1980: 202-203) puts it, the individual "inscribes in himself the power relation" and "becomes the principle of his own subjection." (quoted in Mitchell 1990: 558). This is clearly illustrated by the Maasai attending the meeting inside at the MR. The men were asked to speak, but felt themselves unable to, inscribed by a sense of powerlessness, upheld by their own notions of respect, but also an outside meeting structure lead by the man clearly in power. The format of a Maasai enkiguena changes the power structure-all have equal freedom in theory to speak, and decisions cannot be made without a consensus. This does not mean that power does not still take hold, and that certain individuals will acquiesce to those they feel have more power over them. It does, however, provide a structure for dialogue within which there is more room for negotiation by all involved. That negotiation may happen before or during a meeting, by individuals themselves or through other's they trust to speak for them. It may happen through subtle acts of disobedience such as talking or getting up and walking away while someone else is speaking. It could happen through gestures_-such as pointing a walking stick or olkuma (ritual club) in the direction of particular individuals, leaning authoritatively on it and remaining on a point for several minutes. And it can happen by refusing to agree to the consensus and demanding the meeting re-convene. In all these ways, there are multiple spaces through which to negotiate. Perhaps most importantly, the meeting setting demands a long drawn out dialogue and thus lays open the very terms of negotiation. A decision made at a meeting will never be discussed without discussing the negotiations that lead to the consensus, and thus 
exposing the power dynamics involved in the final decision. If we understand the hidden power as the selfdiscipline it inscribes on subjects, then keeping such power dynamics open and exposed is an important first step in the resistance and reformulation of power.

\section{Conclusion}

Social scientists working with indigenous communities have argued for the need to build "dialogic" or "synergist" dialogues between and among different knowledge spaces (Goldman 2007: Semali and Kincheloe 1991: Sillitoe, Bicker and Pottier 2002; Turnbull 2000; Watson and Huntington 2008, Watson-Verran and Turnbull 1995). These scholars are interested in avoiding the primacy of one knowledge expression (i.e. science) over others, as well as the essentialism of any particular "type" of knowledge (i.e. indigenous knowledge, science) (Goldman 2007, 2011a and b). Our proposal for an enkiguena as a (material) participatory tool, and a (discursive) theoretical approach, provides the tools, vision, and metaphor to build these dialogues. And it does so by utilizing the tools of the people we work with. Politically, one might wonder if the possibility of building the types of dialogues we propose are within reach. We suggest they are, as reflected in growing international politics regarding conservation and local participation; international recognition of and interest in indigenous rights, knowledge, and politics; and finally, but perhaps most importantly, a growing resistance from Maasai to the politics of knowledge as usual. Power is dependent for its very existence on the possibility of resistance (Foucault 1980). Maasai are learning the tools of the trade, arming themselves with Western education (the power of the pen), and contesting conservation knowledge claims from combined "indigenous rights" and "educated" positions.

The local CBO, Ujamaa Community Resource Trust working in Tanzanian Maasailand, has in fact begun to promote Maasai leadership forums and Maasai communication, as a means of empowerment, improved resource management and governance in Maasai areas. The organization has drawn on the ilaigwenak structure discussed above, and utilizes the enkiguena format, to promote improved governance at the local level. In recognition that the customary system was not equitable along gender lines, they are not replicating the original system but drawing from it. Women's leadership forums have been created in addition to the customary men's forums, with joint forums in each location the ultimate goal. Forum members are receiving training in national laws regarding land, resources, and human rights, to strengthen their capacity as modern leaders, yet are encouraged to draw on their own forms of communication, leadership, and decision making. The forums have proven successful in fighting unwanted conservation and development interventions and land grabs, as well as resolving regional (and ethnic) conflicts, and addressing issues of women's empowerment (access to land, inheritance rules) (Goldman, Sinandei, and DeLuca 2014).

We suggest that as scholars and activists we have a responsibility to do more than critique the politics of participation. We should work to help find ways to truly change it, ways that challenge the participation model to open up to new ways of knowing, seeing, and communicating. A part of this process is finding and documenting what does work and how, promoting such projects locally but also learning from them to help promote positive change and ideals of participation elsewhere.

\section{References}

Agrawal, A. and C.C. Gibson. 1999. Enchantment and disenchantment: the role of community in natural resource conservation. World Development 27: 629-49.

Chambers, R. 1997. Whose reality counts? Putting the first last. London: Intermediate Technology Productions.

Cooke, B. and U. Kothari. 2002. Participation: the new tyranny? New York: Zed Books. Ch1.

Dill, B. 2009. The paradoxes of community-based participation in Dar es Salaam. Development and Change 40: 717-743.

Foucault, M. 1980. Power/knowledge: selected interviews and other writings 1972-1977. New York: Pantheon Books.

Goldman, M.J. 2007. Tracking wildebeest, locating knowledge: Maasai and conservation biology understandings of wildebeest behavior in Northern Tanzania. Environment and Planning D: Society and Space 25: 307-331. 
Goldman, M.J. 2011a. Strangers in their own land: Maasai and wildlife conservation in Northern Tanzania. Conservation and Society 9: 65-79.

Goldman, M.J. 2011b. The politics of connectivity across human occupied landscapes: a look at corridors near Nairobi National Park, Kenya. In M.J. Goldman, P. Nadasdy and M.D. Turner (eds.) Knowing nature: conversations at the intersection of political ecology and science studies. Chicago: University of Chicago Press, Pp. 186-202.

Goldman, M.J., M. Sinandei and L. DeLuca, 2014. Conflict resolution, land disputes and peace building in Northern Tanzania: the role of customary institutions. In S. Maphosa, L. DeLuca, and A. Keasle (eds.). Peace from within: community-based peace building in Africa. Pretoria: Africa Institute of South Africa (AISA). Pp. 153-171.

Hodgson, D.L. 2001. Once intrepid warrior: gender, ethnicity and the cultural politics of Maasai development. Bloomington: Indiana University Press.

McCabe, J.T. 2003. Sustainability and livelihood diversification among the Maasai of northern Tanzania. Human Organization 62: 100-111.

McCabe, J.T., S. Perkin and C. Schofield. 1992. Can conservation and development be coupled among pastoral people? An examination of the Maasai of the Ngorongoro Conservation Area, Tanzania. Human Organization 51: 353-366.

McCoy, R. and N. Haenn. 2013. Gentlemen-type rules" and "back room deals" in public participation: natural resource management and a fractured state in North Carolina. Journal of Political Ecology 20: 444459.

McKinnon, K. 2007. Postdevelopment, professionalism, and the politics of participation. Annals of the Association of American Geographers 97: 772-785.

Mitchell, T. 1990. Everyday metaphors of power. Theory and Society 19: 545-577.

Mol, F. 1996. Maasai: language and culture. Narok, Kenya: Mill Hill Missionary.

Ndagala, D.K. 1992. Territory, pastoralists, and livestock: resource control among the Kisongo Maasai. Uppsala: Almqvist and Wiksell International.

Nelson, F. and A. Agrawal. 2008. Patronage or participation? Community-based natural resource management reform in Sub-Saharan Africa. Development and Change 39: 557-585.

Rahnema, M. 1992. Participation. In W. Sachs (ed.) The development dictionary. New York: Zed Books. Pp 116-131.

Ribot, J. 1996. Participation without representation: chiefs, councils, and forestry law in the West African Sahel. Cultural Survival Quarterly 20: 40-44.

Ribot, J.C. 1999. Decentralization, participation and accountability in Sahelian forestry: legal instruments of political-administrative control. Africa 69: 23-65.

Ribot, J.C. 2002. African decentralization: local actors, powers and accountability. Paper Number 8. UNRISD Programme on Democracy, Governance and Human Rights. Geneva: UNRISD.

Rigby, P. 1985. Persistent pastoralists: nomadic societies in transition. London: Zed Books.

Rigby, P. 1992. Cattle, capitalism, and class: Ilparakuyo Maasai transformations. Philadelphia: Temple University Press.

Rocheleau, D. 2003. Participation in context: what's past, what's present, and what's next. In B. Pond, S. Snapp, C. McDougall and A. Braun (eds.) Managing natural resources for sustainable livelihoods: uniting science and participation. London: IDRC.

Rugumayo, C.R. 1997. The politics of conservation area management: on actors, interface and participation. The case of Ngorongoro Conservation Area, Tanzania. PhD dissertation. Trondheim: Norwegian University of Science and Technology.

Saitoti, T. O. 1980. Maasai. New York: Harry N. Abrams, Inc.

Schroeder, R.A. 1999. Geographies of environmental intervention in Africa. Progress in Human Geography 23: 359-378. 
Semali, L.M. and J.L. Kincheloe. 1991. Introduction: what is indigenous knowledge and why should we study it? In L.M. Semali and J.L. Kincheloe (eds.) What is indigenous knowledge? Voices from the academy. New York: Falmer Press. Pp 3-58.

Sillitoe, P., A. Bicker and J. Pottier. 2002. Participating in development: approaches to indigenous knowledge. New York: Routledge.

Scott, J.C. 1987. Weapons of the weak: everyday forms of peasant resistance: New Haven, CT: Yale University Press.

Spencer, P. 2003. Time, space, and the unknown: Maasai configurations of power and providence. New York: Routledge.

Talle, A. 1988. Women at a loss: changes in Maasai pastoralism and their effects on gender relations. Stockholm Studies in Social Anthropology No. 19. Stockholm: University of Stockholm.

Taylor, G. and L. Johansson. 1996. Our voices, our words and our pictures. Plans, truths, and videotapes from Ngorongoro Conservation Area. Forest, Trees and People Newsletter 30.

Thompson, M. and K. Homewood. 2002. Entrepreneurs, elites and exclusion in Maasailand: trends in wildlife conservation and pastoralist development. Human Ecology 30: 107-138.

Turnbull, D. 2000. Masons, tricksters and cartographers: comparative studies in the sociology of scientific and indigenous knowledge. Amsterdam: Harwood Academic.

Waller, R. 1999. Pastoral poverty in a historical perspective. In D. Anderson and B-D. Vigdis (eds.) The poor are not us: poverty and pastoralism. Ohio: Ohio University Press. Pp 20-49.

Watson, A. and O.H. Huntington. 2008. They're here - I can feel them: the epistemic spaces of indigenous and western knowledges. Social and Cultural Geography 9: 257-281.

Watson-Verran, H. and D. Turnbull. 1995. Science and other indigenous knowledge systems. In S. Jasanoff, G.E. Markle, J.C. Peterson and T. Pinch (eds.) Handbook of science and technology studies. Thousand Oaks, CA: Sage. Pp 115-139.

Western, D. 1997. In the dust of Kilimanjaro. Washington, D.C.: Island Press. 